\title{
REVIEW
}

\section{New Vision in Photoprotection and Photorepair}

Marie-Therese Leccia - Celeste Lebbe · Jean-Paul Claudel •

Mridvika Narda $\cdot$ Nicole Basset-Seguin

Received: November 21, 2018 / Published online: January 23, 2019

(C) The Author(s) 2019

\begin{abstract}
Chronic exposure to solar radiation is associated with an increased incidence of skin cancer worldwide and more specifically with non-melanoma skin cancers and actinic keratosis. At the cellular level DNA damage is the main event following ultraviolet (UV) exposure. The kind of lesions produced depends on the wavelength and the energy profile of the radiation, with different photoproducts being formed as a result. Although endogenous DNA repair mechanisms are somewhat effective in repairing DNA, some DNA damage persists and can accumulate with chronic exposure. UV protection strategies, such as sunscreen use, are
\end{abstract}

Enhanced Digital Features To view enhanced digital features for this article go to https://doi.org/10.6084/ m9.figshare.7584212.

M.-T. Leccia

Service de Dermatologie, Centre Hospitalier Universitaire (CHU) de Grenoble, La Tronche, France

C. Lebbe $\cdot$ N. Basset-Seguin ( $₫)$

Policlinique de Dermatologie, Hôpital Saint Louis,

Paris, France

e-mail: nicole.basset-seguin@aphp.fr

J.-P. Claudel

Cabinet de Dermatologie, Tours, France

M. Narda

Innovation and Development, ISDIN, Barcelona, Spain important in limiting further DNA damage. Several published studies have demonstrated the protective effect that regular use of sunscreen can have against the development of skin cancers. Newer options that aim to help repair damaged DNA may have an important role in reducing the incidence of chronic sun exposure-related photoaging and non-melanoma skin cancers. Photolyase, which is capable of repairing cyclobutane dimers formed as a result of DNA irradiation, is one such novel ingredient. In the first part of this paper we review the rationale for a combined treatment approach of photoprotection and photorepair with photolyase. In the second part we evaluate several published clinical studies, which suggest a beneficial effect in preventing new skin lesions in photodamaged skin. A strategy of photoprotection plus photorepair appears to be relevant for all persons with a high level of solar exposure and those at a higher risk for developing skin cancers.

Keywords: DNA repair; Photolyase; Skin cancer; Sunscreen; Ultraviolet radiation

\section{INTRODUCTION}

The omnipresent nature of ultraviolet (UV) radiation in our lives and increasing time spent outdoors has led to a rise in UV-exposure related 
pathologies. In a 2006 report, the World Health Organization (WHO) estimated that around 1.5 million disability-adjusted life years were lost annually through the direct and indirect effects of excessive UV exposure worldwide [1]. Skin cancer is the predominant pathological manifestation resulting from overexposure to UV radiation, with non-melanoma skin cancers (NMSCs) representing more than $90 \%$ of all skin cancers. The WHO recently reported that up to 2-3 million NMSCs are diagnosed worldwide each year, with the USA reporting up to 200,000 new cases of squamous cell carcinoma (SCC) annually, representing $20 \%$ of all new skin cancers $[1,2]$. Due to reporting requirements, precise figures for NMSCs in Europe are difficult to ascertain, but the literature includes estimates of 78,000 cases annually in the UK, and 41,000 in Germany [3]. New strategies to ameliorate the impact of chronic UV damage and thus skin cancers and photoaging are needed.

This article is based on previously conducted studies and does not contain any studies with human participants or animals performed by any of the authors.

\section{UV-MEDIATED SKIN DAMAGE}

Chronic exposure to solar radiation is the most important environmental factor involved in photoaging and in the pathogenesis of skin cancers, especially actinic keratosis (AK) and SCC. The role of UV radiation in the pathogenesis of basal cell carcinoma (BCC) and melanoma appears more complicated, but is probably related to acute exposure during childhood and adolescence.

Cellular DNA is the major cellular target in UV carcinogenesis, through the induction of photo-induced direct and indirect damage that can induce mutations [4]. The chemical nature and the formation of DNA lesions greatly depend on the wavelength of incident photons. UVB radiation, the most energetic and mutagenic component of solar radiations, is directly absorbed by DNA and induces dimeric photoproducts between adjacent pyrimidine bases, namely cyclobutane pyrimidine dimers (CPDs) and pyrimidine (6-4) pyrimidone (6-4PP) photoproducts (Fig. 1) [5]. A causal relationship has been established between UVB DNA lesions and photocarcinogenesis, as indicated by the high proportion of p53 mutations characterized by cytosine (C)-thymine $(\mathrm{T})$ transitions at dipyrimidine sites and CC-TT tandem base substitutions detected at bipyrimidine sites in skin tumors [6]. Although less energetic than UVB, UVA is at least 20-fold more abundant in natural sunlight and is equally involved in skin carcinogenesis. The cytotoxic action of UVA radiation is strongly oxygen dependent and induces oxidative DNA lesions, mainly 8-oxo-7, 8-dihydro-2'-deoxyguanosine [7, 8]. However, UVA also induces large amount of CPDs in whole human skin through a mechanism which differs from that triggered by UVB [9]. In contrast to UVB, UVA preferentially induces the production of CPDs at TT sites without any detectable formation of 6-4PP photoproducts. Interestingly, the research group [9] showed in a subsequent study [10] that the rate of removal of UVA-induced CPDs was lower than those produced by UVB and that more UVA lesions were accumulated in whole skin, emphasizing the crucial role of UVA in skin carcinogenesis. UVA photons are partly absorbed by the upper layers of skin, yet they are also able to penetrate deep into the dermis, whereas UVB radiation is mostly absorbed by the epidermis. The limited capacity of human skin to repair UVA-induced

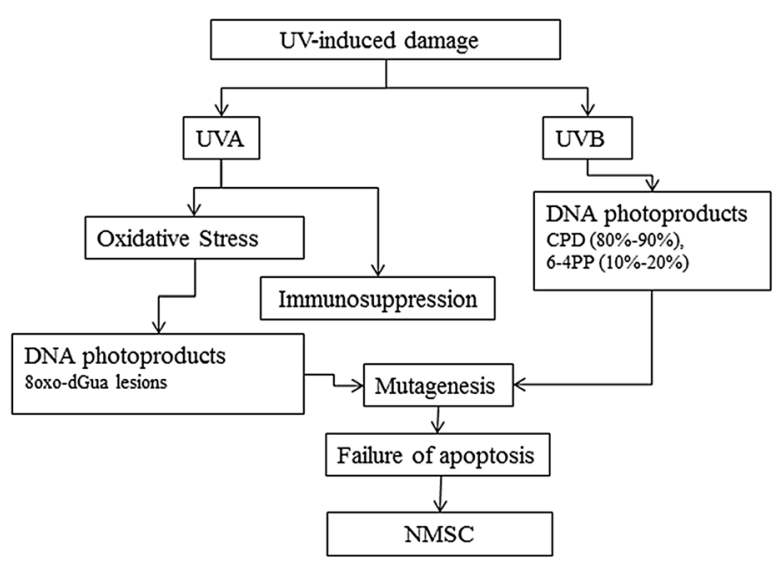

Fig. 1 Ultraviolet $(U V)$ radiation-induced changes ultimately lead to non-melanoma skin cancers (NMSC). CPD Cyclobutane pyrimidine dimer, 6-4PP pyrimidine (6-4) pyrimidone 
DNA damage is responsible for the accumulation of UVA-induced DNA lesions in the whole human skin.

The role of unrepaired DNA lesions comes into play when these stereochemically unwieldy alterations lead to replication errors that result in mutations. Although the majority of spontaneously occurring mutations that accumulate in somatic cells throughout a person's lifetime may go unnoticed without having any major effects, some can alter key cellular functions, leading to cancer and aging [11]. Different mutations might evolve differently in sun-exposed skin depending on clonal expansion and the positive selection of the cells involved. At any given time sun-exposed skin has been described as a patchwork of thousands of evolving clones with over one-quarter of the cells carrying cancer-causing mutations while maintaining the physiological functions of the epidermis [11]. Loss of p53-induced protective mechanisms results in the accumulation of additional mutations and chromosome instability, culminating in abnormal keratinocyte proliferation and resulting in a gradual upregulation of the pre-tumorigenic (AK) and tumorigenic (SCC) lesions when compared to normal skin and non-tumorigenic lesions [12].

\section{UV AND NMSC}

Worldwide, NMSC incidence ranges from the highest rates in Australia (> 1000/100,000 person-years for BCC) to the lowest rates in parts of Africa $(<1 / 100,000$ person-years for BCC). In Europe the highest incidence rates for BCC and SCC have been reported in the UK [13]. In France, BCC and AK represent 1 and $5 \%$ of dermatological consultations, respectively [14]. Sixty percent of SCC arise from a lesion diagnosed clinically as a solar keratosis in the previous year [15]. The relative risk of malignant transformation of a pre-existing AK lesion is 2.2fold higher than the risk of SCC in normal skin [16]. SCCs are the most frequent (58\%) skin neoplasm coexisting with AK, followed by BCC (30\%) [17]. Up to $69 \%$ of SCCs and $53 \%$ of AK lesions are reported to be positive for p53 mutations [18]. There is an increase in mutation burden with the progression from normal UVexposed skin to AK and then to SCC [19]. The development of skin SCCs involves a large number of chromosomal aberrations, with the most significant of mutated genes being TP53, NOTCH1-2, FAT1, MLL2 and KNSTRN [20-24].

In contrast, BCCs arise with no established precursor and present with a high mutation rate. A high prevalence of UV signature. BCCs are driven by the Sonic Hedgehog (Hh) pathway, with a high frequency of mutations of PTCH1 (73\%), SMO (20\%) and SUFU (8\%). Other less frequently altered driver genes include TP53, MYCN, PPP6C, STK19 LATS1, ERBB2, PIK3CA and the RAS family [25-29].

Due to their high prevalence, NMSCs are altogether among the five most expensive cancer diseases according to the Medicare Beneficiary Survey 1992-1995 (Medicare being the health-insurance provider for Americans administered by the US government) [30]. Recent temporal trends investigated in Australia, Canada and the USA indicated a more than twofold increase in NMSC prevalence, as well as a higher frequency on sun-exposed areas, implicating long-term, repeated UV radiation exposure as a major causal factor. Some countries also report an association between increasing incidences of NMSCs with decreasing latitude, i.e. higher UV radiation levels [13].

When UV protection strategies are being developed, high-risk populations must be given special consideration. Risk factors include Fitzpatrick skin type I to III, baldness, male gender, older age, precancerous skin conditions (AK and Bowen's disease), immune deficiency and the frequent use of sunbeds [31]. A higher lifetime exposure to the sun or other sources of UV radiation is clearly associated with a higher incidence of SCCs and BCCs. Outdoor workers run a significantly increased risk for developing NMSCs [32]. A recent analysis of the European multi-center EPIDERM study showed a fourfold increased odds of developing AK among outdoor workers, with the risks increasing with increasing duration of outdoor exposure and health literacy [33]. 


\section{PHOTOPROTECTION IN THE 21ST CENTURY}

Long before epidemiological data on UV-related damage were available, protecting ourselves from the sun came naturally. Traditional practices, such as avoiding sun exposure at peak hours and using wide-brimmed hats or sun umbrellas, were the norm. Today sunscreens with the appropriate sun protection factor (SPF) and protection spectrum are the mainstay of our strategy for reducing UV damage. Typical sunscreen lotions or creams may contain physical and/or organic filters, antioxidant compounds and mixtures thereof. Technologies such as UV absorbers that are added to laundry detergents and potentially increase the UV protection factor by $400 \%$ [34] are an interesting approach to be explored further.

The efficacy of sunscreen use in preventing skin cancer is well documented. In 1993 Thompson showed that the regular use of sunscreen (SPF 17) by 588 Australians resulted in fewer new skin lesions and a decrease of solar keratosis compared to subjects who used a base cream minus the active ingredients of the sunscreen [35]. In a US study, the use of sunscreen (SPF 29) reduced the number of AK lesions over 2 years in individuals with lighter skin (skin types 1 and 2) and in those with more initial AK lesions [36]. In another study from Australia, the daily use of sunscreen (SPF 15) over 4.5 years lowered the incidence of SCC significantly versus those who did not apply sunscreen daily, although a similar reduction was not seen in BCC [37]. An Australian trial that compared daily sunscreen use to discretionary sunscreen use reported a decrease in the average rate of acquisition of solar keratoses in the daily sunscreen use group over a 2-year period [38]. In immune-compromised organ transplant recipients, daily use of sunscreen prevented the development of AK and SCC [39]. The WHO recommends the liberal use of a broad-spectrum sunscreen with at least SPF 15 to be re-applied every $2 \mathrm{~h}$, or after sweating, swimming, working, playing or exercising outdoors. However, compliance in regular sunscreen use is a challenge, mainly due to the poor cosmetic qualities and cost of sunscreen products. More recently, concerns about the possible ill-effects of certain constituents of sunscreens have added to the confusion in the public mind regarding the use sunscreens. Additionally, it has been reported that chronic activation of the DNA damage response, mostly in P53 mutated mice model, could be deleterious [40]. However, no study conducted to date has shown that photolyaseinduced repair could be harmful.

\section{NEW STRATEGIES IN PHOTOPROTECTION}

The future of photoprotection looks promising. The availability of new ingredients has led to considerable improvement in the texture, photostability, water resistance and efficacy of sunscreens. An increasing number of sunscreens offer a more complete protection by including additional ingredients, such as antioxidants, or natural molecules, such as herbal extracts, lichens and biomolecules, as photoprotection alternatives and enhancers [41]. Plankton extract, which contains DNA repair enzyme photolyase, is one such novel ingredient that is being incorporated into sunscreen to complement intrinsic DNA repair and thus expand the photoprotective abilities of sunscreens to photorepair.

The 2015 Nobel Prize in chemistry recognized the work of Aziz Sancar from the University of North Carolina for his work elucidating the mechanisms of DNA repair by photolyase [42]. Photolyase, a class of flavoproteins, repairs DNA photoproducts formed due to UVB exposure through the absorption of blue light [43-46]. Two different kinds of photolyases exist; these are classified as CPD photolyase and (6-4) photolyase based on the class of photoproducts they repair. Although structurally similar, the two photolyases are very specific in their action against one or the other type of photoproducts they repair. Photolyase isolated from the cyanobacterium Anacystis nidulans is specific for CPD photoproducts; this phytolyase breaks CPDs and restores the original monomeric state (Fig. 2). Photolyase is not innately present in humans, who possess other 


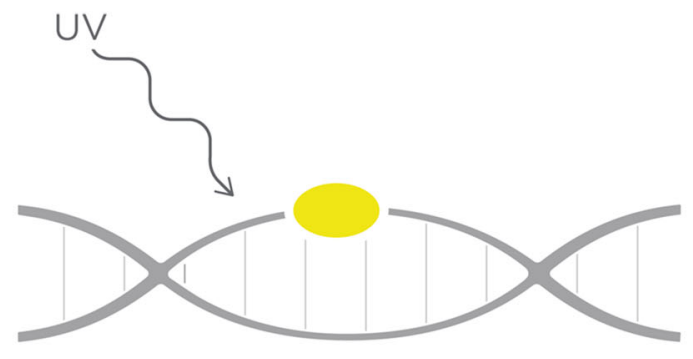

Formation of CPD in DNA exposed to UVR

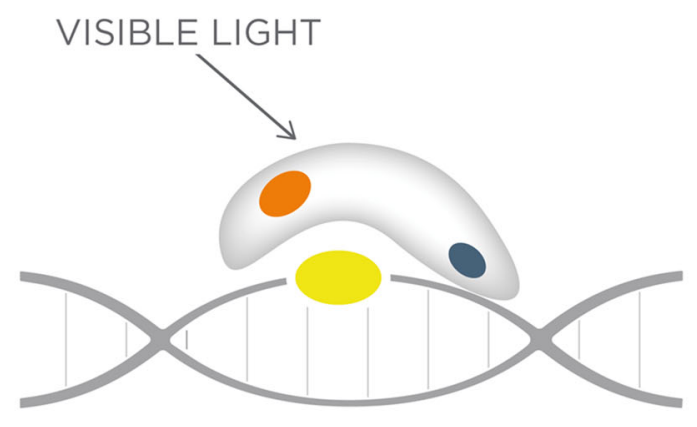

Photolyase binds CPD lesion

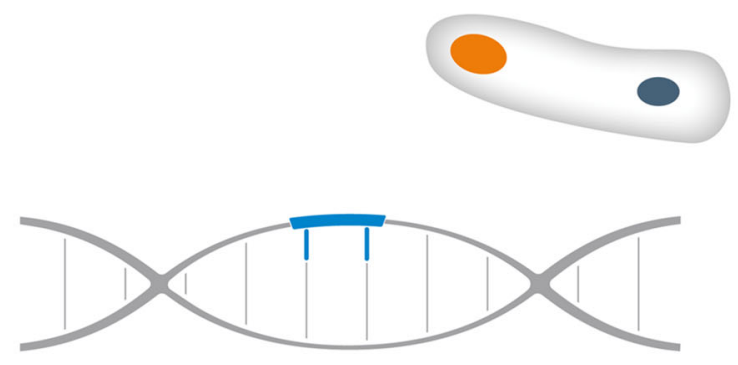

Photoreactivated photolyase cleaves CPD reverting to monomeric DNA

Fig. 2 Cyclobutane pyrimidine dimer $(C P D)$ repair by photolyase action following photoreactivation. UVR UV radiation

DNA repair mechanisms, such as the nucleotide excision repair (NER) pathway, that are reported to repair UV-induced DNA damage. NER is, however, more effective in recognizing and repairing pyrimidine pyrimidones and relatively inefficient in repairing CPDs [47-50]. CPD repair efficiency further decreases with advancing age. The possibility of incorporating photolyase-and with it the ability to repair UV-induced DNA damage-in a sunscreen adds an exciting new dimension to the strategic approach against UV damage.

Early work with the DNA repair enzyme T4 endonuclease $\mathrm{V}$ showed that topically applied T4N5 encapsulated in liposomes enhanced the removal of DNA photoproducts in human and mouse skin and reduced the incidence of skin cancer in mice [51]. Stege et al. demonstrated that topical treatment of human skin with liposomes containing biologically active photolyase and subsequent exposure to photoreactivating radiation was effective in partially removing UVB radiation-induced CPDs from the epidermis of treated skin areas. A 45\% reduction in the number of CPDs was reported in 12 volunteers who used a topical application of a liposome formulation with CPD photolyase followed by exposure to sunlight [52, 53]. Compared to a previous clinical study in xeroderma pigmentosum (XP) patients in whom T4N5 treatment resulted in approximately 20\% dimer removal in $6 \mathrm{~h}$, photolyase treatment resulted in the removal of $40-45 \%$ of CPDs present in UVB-irradiated normal human skin immediately after photoreactivation, suggesting that photolyase may be more efficient than T4N5 in CPD repair activity [54]. In another study, the topical application of DNA repair enzymes to the sun-damaged skin of patients with XP lowered the rate of new AK lesions and BCCs compared to those using the placebo lotion by 68 and 30\%, respectively, during 1 year of treatment [55].

In 2000, Stege et al. concluded their publication with these words "Exogenous application of photolyase differs from conventional photoprotection through its ability to remove damage that has already occurred. This enzyme therapy approach could thus be ideally combined as an after-sun strategy with conventional sunscreens to provide photoprotection and repair at the same time" [52]. At the time, it still remained to be seen whether such a product formulation was feasible, considering the inherent complications of combining UV filters and natural plankton extract, the source of photolyase enzyme. A product that combined plankton extract (source of photolyase) encapsulated in 
liposomes to promote epidermal penetration with UV filters with very high SPF protection was ultimately developed and studied in several clinical trials (marketed in Europe as Eryfotona; ISDIN, Barcelona, Spain).

\section{FROM PHOTOPROTECT TO PHOTOREPAIR?}

Several clinical trials have been published on the use of a topical product containing the DNA repair enzyme photolyase encapsulated in liposomes and a very high SPF sunscreen, either alone or as an adjuvant therapy, in patients with AK (Table 1). As these studies were conducted with a small sample size and were sometimes lacking a control group, we consider them "proof of concept" studies that, nevertheless, report important results. Puviani et al. reported results from a six-patient trial in which all patients with visible AK lesions on the face and the scalp were treated with the topical product, either as an adjuvant or as sole treatment, applied twice daily as a cream or fluid formulation for 4-8 weeks. Clinical photographs of the skin lesions at baseline and after treatment showed an improvement of the field cancerization and a reduction in the number of AK lesions (Fig. 3) [56].

Another trial was conducted with eight XP patients [57] who were treated with the Eryfotona product for a period of 12 months. The rate of new skin lesions (AK, BCC and SCC) during active treatment and that during the 12 months prior to use of the topical product were compared. The number of new AK, BCC and SCC lesions during the 1-year treatment with the topical product were five, three and zero, respectively; in comparison, there were 14, 6.8 and three lesions, respectively, in the 12-month period prior. These results show a reduction of 65,56 and $100 \%$ in the number of $\mathrm{AK}, \mathrm{BCC}$ and SCC lesions, respectively, in the $\mathrm{XP}$ patients following use of the topical product.

Rstom et al. reported results from a clinical trial with 14 patients aged 45-65 years with Grade I and Grade II AK and other cutaneous signs of actinic damage. AK lesions were documented by clinical photography, optical polarized light dermoscopy and confocal microscopy in vivo. After treatment with the topical product containing photolyase encapsulated in liposomes and very high SPF sunscreen for 120 days, marked clinical improvement was reported, with a reduction of erythema and desquamation for grade I AK lesions [58].

Puig et al. compared the use of the same topical product containing photolyase encapsulated in liposomes to the use of a sunscreen product with comparable SPF protection. Thirteen patients with multiple AK lesions in a sunexposed skin area were treated for 4 weeks. Clinical assessment, dermoscopy, confocal microscopy and histopathology evaluation showed an improvement in AK lesions after treatment with the Eryfotona product. Erythema, scaling, pigmentation and follicular plugs improved significantly in the Eryfotonatreated group. In contrast, no improvement was noted in the three patients that used the sunscreen. An absence of epidermal atypia and decreased proliferation markers Ki67 and proliferating cell nuclear antigen (PCNA) were reported in $50 \%$ of the samples following treatment with the topical cream. The investigators concluded that application of the product containing photolyase in liposomes and UV filters, twice a day for 4 weeks, led to an improvement in field cancerization in patients with AK lesions [59].

Laino et al. [60] assessed the effects of the photolyase product on thermographic parameters, as a secondary aim of their active telethermography study of field cancerization. Active telethermography is a technique used to observe the imaging of a hyperthermic halo (HH) surrounding the tumor. In this 9-month study with 30 patients (27 completed the study), these authors observed the presence of HHs in all patients, with a significant modification of the extension and thermal parameters of these areas after treatment. With treatment, they observed a reduction from a mean halo area of $3.46 \mathrm{~cm}^{2}$ at baseline to a mean halo area of $0.64 \mathrm{~cm}^{2}$ at 9 months, with the values of thermal recovery time progressively increasing 
Table 1 Summary of clinical studies conducted to date with the finished product Eryfotona, which contains sun protection factor 50 plus photolyase

\begin{tabular}{|c|c|c|}
\hline Study & Study design & Results \\
\hline $\begin{array}{l}\text { Puviani et al. } \\
\text { (2013) [56] }\end{array}$ & $\begin{array}{l}6 \text { patients } \\
\text { Treated with product as adjuvant or as sole } \\
\text { treatment, for } 4-8 \text { weeks } \\
\text { Assessed with clinical photographs }\end{array}$ & $\begin{array}{l}\text { Improvement of field cancerization, reduction in } \\
\text { number of } \mathrm{AK}\end{array}$ \\
\hline $\begin{array}{l}\text { Gaston et al. } \\
\qquad(2014)[57]\end{array}$ & $\begin{array}{l}8 \text { patients with XP } \\
\text { Treated for } 12 \text { months } \\
\text { Compared rate of new skin lesions (AK, BCC and } \\
\text { SCC) during active treatment vs. the } 12 \text { months } \\
\text { prior to use of the product }\end{array}$ & $\begin{array}{l}\text { Number of new lesions of } \mathrm{AK}, \mathrm{BCC} \text { and } \mathrm{SCC} \\
\text { lesions during treatment period: AK, 5; BCC, 3; } \\
\text { SCC, } 0 \\
\text { Number of lesions before treatment: } 14,6.8 \text { and 3, } \\
\text { respectively ( } 65,56 \text { and } 100 \% \text { reduction, } \\
\text { respectively) }\end{array}$ \\
\hline $\begin{array}{l}\text { Rstom et al. } \\
\text { (2014) [58] }\end{array}$ & $\begin{array}{l}14 \text { patients, Grade I-II AK and other signs of } \\
\text { actinic damage } \\
\text { Treated for } 3 \text { months } \\
\text { Assessed on clinical photography, optical polarized } \\
\text { light dermoscopy and confocal microscopy in vivo }\end{array}$ & $\begin{array}{l}\text { Marked clinical improvement with reduction of } \\
\text { erythema and desquamation for grade I AK } \\
\text { lesions }\end{array}$ \\
\hline $\begin{array}{l}\text { Puig et al. } \\
\qquad(2014) \text { [59] }\end{array}$ & $\begin{array}{l}13 \text { patients } \\
\text { Treated for } 4 \text { weeks } \\
\text { Compared the use of the product with a sunscreen } \\
\text { product with comparable SPF } \\
\text { Clinical assessment, dermoscopy, confocal } \\
\text { microscopy and histopathology evaluation }\end{array}$ & $\begin{array}{l}\text { Improvement in AK lesions after treatment with } \\
\text { Eryfotona product. Erythema, scaling, } \\
\text { pigmentation and follicular plugs improved } \\
\text { significantly in Eryfotona-treated group } \\
\text { No improvement in the } 3 \text { patients who used } \\
\text { sunscreen alone } \\
50 \% \text { of the samples reported absence of epidermal } \\
\text { atypia and decreased proliferation markers Ki67 } \\
\text { and PCNA with treatment }\end{array}$ \\
\hline $\begin{array}{l}\text { Laino et al. } \\
\qquad(2015)[60]\end{array}$ & $\begin{array}{l}30 \text { patients ( } 27 \text { completed) } \\
\text { Treated for } 9 \text { months } \\
\text { Telethermography study of field cancerization } \\
\text { Secondary aim was to assess effects of the } \\
\text { photolyase product on thermographic parameters }\end{array}$ & $\begin{array}{l}\text { Hyperthermic halos present in all patients. } \\
\text { Significant modification of extension and thermal } \\
\text { parameters after treatment } \\
\text { Reduction in halo area with treatment } \\
\text { Thermal recovery time increased toward healthy } \\
\text { skin values } \\
\text { Halo disappeared completely in } 5 \text { cases }\end{array}$ \\
\hline
\end{tabular}


Table 1 continued

\begin{tabular}{|c|c|c|}
\hline Study & Study design & Results \\
\hline $\begin{array}{l}\text { Eibenshutz } \\
\text { et al. (2016) } \\
{[61]}\end{array}$ & $\begin{array}{l}30 \text { patients } \\
\text { Treated for } 9 \text { months } \\
\text { Randomized, assessor-blinded, controlled clinical } \\
\text { trial } \\
\text { Compared effects of product vs. SPF } 50+\text { in field } \\
\text { cancerization, after PDT }\end{array}$ & $\begin{array}{l}\text { One session PDT reduced mean number of AK } \\
\text { lesions to } 2.0 \text { in Eryfotona group, } 0.6 \text { in sunscreen } \\
\text { group } \\
\text { Sunscreen group showed increase in number of AK } \\
\text { lesions (mean } 3.6 \text { lesions),vs. } 1 \text { in Eryfotona group } \\
\text { No patient in Eryfotona group needed further PDT } \\
\text { or other field-targeted treatment; } 66 \% \text { of } \\
\text { sunscreen group needed further PDT }\end{array}$ \\
\hline $\begin{array}{l}\text { Vaño-Galvan } \\
\text { et al. (2016) } \\
{[62]}\end{array}$ & $\begin{array}{l}41 \text { patients, skin phototype II } \\
\text { Treated for } 6 \text { months } \\
\text { Prospective observational study } \\
\text { assessing topical product plus cryotherapy }\end{array}$ & $\begin{array}{l}84 \% \text { reduction in mean number of AK lesions vs. } \\
\text { baseline } \\
\text { Mean } 0.27 \text { new AK lesions present after } 1 \text { month, } \\
0.76 \text { after } 6 \text { months } \\
\text { No new lesions in patients who had not required } \\
\text { additional cryotherapy sessions } \\
\text { More effective in thin AK lesions than in } \\
\text { hypertrophic AK lesions } \\
1 / 3 \text { patients showed complete response; all others, } \\
\text { partial response }\end{array}$ \\
\hline $\begin{array}{l}\text { Navarette- } \\
\text { Dechent } \\
\text { et al. }(2016) \\
\text { [63] }\end{array}$ & $\begin{array}{l}\text { Case series, } 9 \text { patients with field cancerization and } \\
\text { AK } \\
\text { Treated for } 3 \text { months, no concomitant treatments, } \\
\text { no treatment } 3 \text { months prior }\end{array}$ & $\begin{array}{l}\text { All patients had partial response } \\
\text { All had at } \geq 50 \% \text { reduction in lesion number } \\
\text { Lesion count decreased from } 13.4 \text { to } 3.1\end{array}$ \\
\hline $\begin{array}{l}\text { Moscarella } \\
\text { et al. (2017) } \\
{[64]}\end{array}$ & $\begin{array}{l}36 \text { patients } \\
\text { Randomized, double-blind, parallel-group pilot } \\
\text { study of the product vs. SPF } 50+\text { sunscreen as } \\
\text { comparator } \\
6 \text { months } \\
\text { Assessed on clinical evaluation, dermoscopy and } \\
\text { reflectance confocal microscopy }\end{array}$ & $\begin{array}{l}\text { Both groups significantly improved vs. baseline } \\
\text { Mild AK subgroup ( } \leq 10 \text { lesions) had greater } \\
\text { improvement with Eryfotona than did the } \\
\text { sunscreen-alone group ( }-3.8 \text { vs. }-2.7 \text { lesions, } \\
\text { respectively) and fewer new lesions }(+0.01 \text { and }+ \\
\text { 1.5, respectively) }\end{array}$ \\
\hline
\end{tabular}

$\overline{A K}$ actinic keratosis, $B C C$ basal cell carcinoma, $P C N A$ proliferating cell nuclear antigen, $P D T$ photodynamic therapy, $S C C$ squamous cell carcinoma, $S P F$ sun protection factor, $X P$ xeroderma pigmentosum

toward the perilesional values of healthy skin; in five cases, the halo disappeared completely.
A recent randomized, assessor-blinded, controlled clinical trial compared the effects of the topical product in the treatment of field 

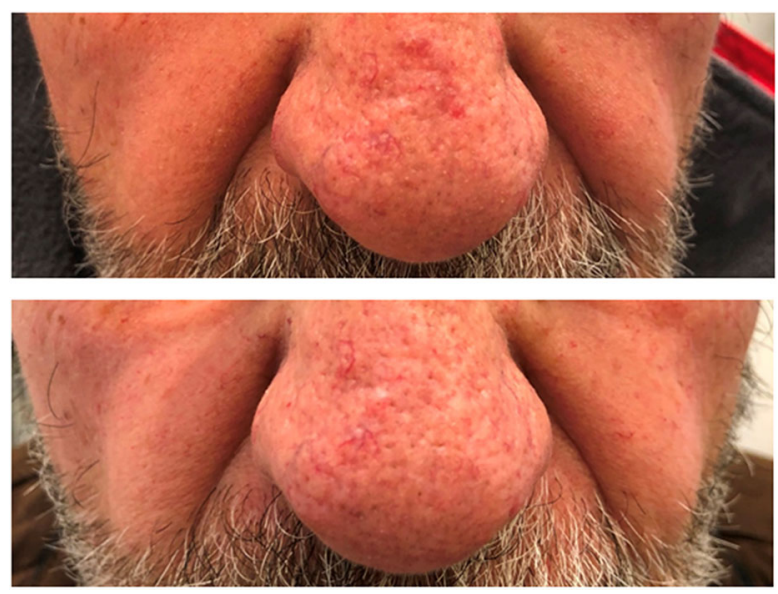

Fig. 3 Clinical improvement in the appearance of the actinic keratosis lesions in a 65-year old man after 6 weeks of treatment with a medical device with very high sun protection factor and photolyase. Pictures are reproduced courtesy of Dr. Mario Puviani, Unit of Dermatology and Surgical Dermatology, Sassuolo Hospital, Sassuolo, Modena, Italy. Informed consent was obtained from the patient for being included in the paper

cancerization in comparison with sunscreen (SPF 50+) in patients who had undergone successful photodynamic therapy (PDT) for AK [61]. PDT is a well-established therapeutic approach for the treatment of AK which clears the lesions and improves field cancerization. However more than $20 \%$ of patients need a follow-up procedure in following months following PDT treatment as the lesions tend to reappear. Thirty patients with multiple skin lesions who underwent successful PDT were randomized 1:1 into an Eryfotona (Ery) group or sunscreen SPF $50+$ (SS) group. All patients underwent one standardized session of methylaminolaevulinate PDT, which reduced the mean number of AK lesions to 2.0 lesions in the Ery group and to 0.6 lesions in the SS group. However, at the 9-month evaluation following PDT, the SS group showed a progressive increase in the number of AK lesions (mean 3.6 lesions); in contrast, the mean number of AK lesions in the Ery group at 9 months was 1 . During the 9-month observational period no patient in the Ery group needed an additional PDT session or another field-targeted treatment, whereas 66\% of the SS group needed an additional PDT session [61]. Ery improved, in comparison with sunscreen, the clinical outcomes in AK subjects after PDT treatment. These results suggest that DNA photorepair mechanisms, such as that provided by photolyase, in combination with UV filters may provide a benefit over simple sunscreens.

Vaño-Galvan et al. [62] conducted a prospective observational study in 2016 in which they assessed the performance of the topical product plus cryotherapy in 41 patients with AK and with skin phototype II. Patients who had received PDT in the 6 months prior to study initiation or any $\mathrm{AK}$ treatment in the 3 months prior to study initiation were excluded. The product was applied twice daily, starting the day after the first cryotherapy session. At visits at baseline and at 1,3 and 6 months after treatment initiation, a dermatologist evaluated the need for further cryotherapy. The investigators looked at the number, location and severity of existing lesions and occurrence of new AK lesions or SCCs. After 6 months of treatment they found an $84 \%$ reduction in mean number of $\mathrm{AK}$ lesions compared with baseline. Regarding the occurrence of new AK lesions, they found a mean number of 0.27 new lesions present after 1 month and 0.76 new lesions after 6 months, with no new lesions in those patients who had not required additional cryotherapy sessions beyond the baseline visit. The treatment was found to be more effective in patients with thin $\mathrm{AK}$ lesions than in those with hypertrophic AK lesions. Overall, approximately one-third of the patients showed complete response; all others showed partial response.

The same year, Navarette-Dechent et al. [63] reported a case series of nine South American patients with field cancerization and AK, who were treated for 3 months, with no concomitant treatments; there had also been no treatment in the 3 months prior to study initiation. All patients had partial response and had a minimum 50\% reduction in lesion number, with the lesion count decreasing from 13.4 to 3.1 , a $76.6 \%$ absolute reduction.

In 2017, Moscarella et al. [64] conducted a randomized, double-blind, parallel-group pilot study of the product in which they used a 
commercially available SPF50 + sunscreen as a comparator, in 36 patients. After 6 months, both groups showed significant improvement in the endpoints of clinical evaluation, dermoscopy and reflectance confocal microscopy, while in the "mild" AK subgroup $(\leq 10 \mathrm{AK}$ lesions in target area at baseline), the Eryfotona group showed a greater improvement than the sunscreen alone group ( -3.8 lesions vs. -2.7 lesions, respectively) and fewer new lesions (+0.01 and +1.5 , respectively).

Although it would be desirable to have a randomized, controlled, double-blinded, multicenter clinical trial to better demonstrate the role of photolyase in the product Eryfotona, the authors recognize that conducting such a trial is faced with challenges. However, we do believe that there is sufficient existing clinical data, as discussed above, to suggest that the topical application of a product containing the DNA repair enzyme photolyase in the form of a plankton extract and UV filters with very high SPF may offer a clinically perceptible benefit compared to a classical sunscreen product.

\section{PHOTOREPAIR IN DAILY CARE REGIMEN}

Photoprotection with photorepair incorporated in the same product is at the frontier of new strategies in photoprotection today. The difference from conventional photoprotection lies in the fact that photolyase is capable of repairing UV-induced DNA damage that has already occurred, whereas a sunscreen, at best, protects against accruing further damage. In addition, while sunscreens are recommended for use when excessive solar exposure is expected, typically in summer months, a photorepair product should be used all year around to achieve ideal results in reverting CPD-mediated damage. Patients need to be reminded that photolyase is a photoreactive enzyme and needs some light for its activity (though a few minutes of light is sufficient) and that the product should be applied on clean skin before other skincare products are applied. The Eibenshutz study [61] is an example of how it can be combined with PDT treatment for multiple actinic lesions.
Further studies are needed to demonstrate efficacy when used in combination with other AK treatments.

Krutmann et al. in their review of the literature on a topical product containing photolyase and very high SPF UV filters suggested an algorithm for adjuvant photoprotection that recommends the use this product for persons at moderate to high risk, i.e., those with a history of AK, BCC/SCC, organ transplant recipients or other immunosuppressed individuals, and those with clinically relevant photodamage [65]. However, if we consider photocarcinogenesis to be a result of actinic damage accumulated over years of UV exposure, it seems that all at-risk populations for developing NMSC or AK, such as outdoor workers, outdoor sports persons, those with Fitzpatrick skin type $<$ III and/or those with a family history of NMSC and/or risky behavior, such as previous sunburn history or sunbed use, would benefit from a photoprotection and photorepair strategy. Good texture and feel of the product are keys to achieve patient compliance for longterm topical treatments. Improved aesthetic quality with good sensory and tactile profiles should ensure the use of these products as recommended [66].

\section{ACKNOWLEDGEMENTS}

Funding. The meeting of all authors of this paper was supported by ISDIN, Barcelona, Spain. No funding or sponsorship was received for this study or publication of this article.

Authorship. All named authors meet the International Committee of Medical Journal Editors (ICMJE) criteria for authorship for this article, take responsibility for the integrity of the work as a whole, and have given their approval for this version to be published.

Disclosures. Marie-Therese Leccia is a consultant for ISDIN. Celeste Lebbe is a consultant for ISDIN. Jean-Paul Claudel is a consultant for ISDIN. Mridvika Narda is a employee and consultant for ISIN. Nicole Basset-Seguin is a 
consultant for ISDIN. Nicole Basset-Sequin is an Editorial Board Member of the journal.

Compliance with Ethics Guidelines. This article is based on previously conducted studies and does not contain any studies with human participants or animals performed by any of the authors.

Open Access. This article is distributed under the terms of the Creative Commons Attribution-NonCommercial 4.0 International License (http://creativecommons.org/licenses/ by-nc/4.0/), which permits any noncommercial use, distribution, and reproduction in any medium, provided you give appropriate credit to the original author(s) and the source, provide a link to the Creative Commons license, and indicate if changes were made.

\section{REFERENCES}

1. Lucas R, McMichael T, Smith W, Armstrong B. Solar ultraviolet radiation: Global burden of disease from solar ultraviolet radiation. In: Environmental Burden of Disease Series, No. 13. P 9. Available from http://www.who.int/uv/publications/solaradgbd/ en/. Accessed 29 Nov 2018.

2. World Health Organization (WHO). Ultraviolet radiation (UV). Skin cancers. http://www.who.int/ uv/faq/skincancer/en/index1.html. Accessed 28 Nov 2018.

3. Cakir BÖ, Adamson P, Cingi C. Epidemiology and economic burden of nonmelanoma skin cancer. Facial Plast Surg Clin North Am. 2012;20(4):419-22.

4. Cadet J, Douki T, Ravanat JL. Oxidatively generated damage to cellular DNA by UVB and UVA radiation. Photochem Photobiol. 2015;91:140-55.

5. Cadet J, Sage E, Douki T. Ultraviolet radiation-mediated damage to cellular DNA. Mutat Res. 2005;571:3-17.

6. Pfeifer GP, Besaratinia A. UV wavelength-dependent DNA damage and human non-melanoma and melanoma skin cancer. Photochem Photobiol Sci. 2012;11(1):90-7.

7. de Gruijl FR, Rebel H. Early events in UV carcinogenesis-DNA damage, target cells and mutant p53 foci. Photochem Photobiol. 2008;84(2):382-7.
8. Beani JC. Ultraviolet A-induced DNA damage: role in skin cancer. Bull Acad Natl Med. 2014;198(2):273-95.

9. Mouret S, Baudouin C, Charveron M, Favier A, Cadet J, Douki T. Cyclobutane pyrimidine dimers are predominant DNA lesions in whole human skin exposed to UVA radiation. Proc Natl Acad Sci USA. 2006;103(37):13765-70.

10. Mouret S, Leccia MT, Bourrain JL, Douki T, Beani JC. Individual photosensitivity of human skin and UVA induced pyrimidine dimers in DNA. J Invest Dermatol. 2011;131(7):1539-46.

11. Martincorena I, Campbell PJ. Somatic mutation in cancer and normal cells. Science. 2015;349(6255):1483-9.

12. Hussein MR, Al-Badaiwy ZH, Guirguis MN. Analysis of p53 and bcl-2 protein expression in the nontumorigenic, pretumorigenic, and tumorigenic keratinocytic hyperproliferative lesions. J Cutan Pathol. 2004;31:643-51.

13. Lomas A, Leonardi-Bee J, Bath-Hextall F. A systematic review of worldwide incidence of nonmelanoma skin cancer. $\mathrm{Br} \mathrm{J}$ Dermatol. 2012;166(5):1069-80.

14. Bernard P, Dupuy A, Sasco A, et al. Basal cell carcinomas and actinic keratoses seen in dermatological practice in France: a cross-sectional survey. Dermatology. 2008;216(3):194-9.

15. Marks R. The epidemiology of non-melanoma skin cancer: who, why and what can we do about it. J Dermatol. 1995;22(11):853-7.

16. Anwar J, Wrone DA, Kimyai-Asadi A, Alam M. The development of AK into invasive SCC: evidence and evolving classification schemes. Clin Dermatol. 2004;22(3):189-96.

17. Traianou A, Ulrich $\mathrm{M}$, Apalla Z, et al. Risk factors for actinic keratosis in eight European centres: a casecontrol study. Br J Dermatol. 2012;167[Suppl 2]:36-42.

18. Lee CS, Bhaduri A, Mah A, et al. Recurrent point mutations in the kinetochore gene KNSTRN in cutaneous squamous cell carcinoma. Nat Genet. 2014;46(10):1060-2.

19. Chitsazzadeh V, Coarfa C, Drummond JA, et al. Cross-species identification of genomic drivers of squamous cell carcinoma development across preneoplastic intermediates. Nat Commun. 2016;7:12601. 
20. Pickering CR, Zhou JH, Lee JJ, et al. Mutational landscape of aggressive cutaneous squamous cell carcinoma. Clin Cancer Res. 2014;20(24):6582-92.

21. Sekulic A, Migden MR, Lewis K, et al. Pivotal ERIVANCE basal cell carcinoma (BCC) study: 12-month update of efficacy and safety of vismodegib in advanced BCC. J Am Acad Dermatol. 2015;72(6):1021-6.

22. Harwood CA, Proby CM, Inman GJ, Leigh IM. The promise of genomics and the development of targeted therapies for cutaneous squamous cell carcinoma. Acta Derm Venereol. 2016;96(1):3-16.

23. Watt SA, Purdie KJ, den Breems NY, et al. Novel CARD11 mutations in human cutaneous squamous cell carcinoma lead to aberrant NF- $\kappa B$ Regulation. Am J Pathol. 2015;185(9):2354-63.

24. Ganesan P, Ali SM, Wang K, et al. Epidermal growth factor receptor P753S Mutation in cutaneous squamous cell carcinoma responsive to cetuximab-based therapy. J Clin Oncol. 2016;34(5):34-7.

25. Bonilla X, Parmentier L, King B, et al. Genomic analysis identifies new drivers and progression pathways in skin basal cell carcinoma. Nat Genet. 2016;48(4):398-406.

26. Sharpe HJ, Pau G, Dijkgraaf GJ, et al. Genomic analysis of smoothened inhibitor resistance in basal cell carcinoma. Cancer Cell. 2015;27(3):327-41.

27. Atwood SX, Sarin KY, Whitson RJ, et al. Smoothened variants explain the majority of drug resistance in basal cell carcinoma. Cancer Cell. 2015;27(3):342-53.

28. Jaju PD, Nguyen CB, Mah AM, et al. Mutations in the kinetochore gene KNSTRN in basal cell carcinoma. J Invest Dermatol. 2015;135(12):3197-200.

29. Pricl S, Cortelazzi B, Dal Col V, et al. Smoothened (SMO) receptor mutations dictate resistance to vismodegib in basal cell carcinoma. Mol Oncol. 2015;9(2):389-97.

30. Housman TS, Feldman SR, Williford PM, et al. Skin cancer is among the most costly of all cancers to treat for the medicare population. J Am Acad Dermatol. 2003;48(3):425-9.

31. Flohil SC, van der Leest RJ, Hofman Dowlatshahi EA. Prevalence of actinic keratosis and its risk factors in the general population the Rotterdam Study. J Invest Dermatol. 2013;133(8):1971-8.

32. John SM, Trakatelli M, Ulrich C. Non-melanoma skin cancer by solar UV: the neglected occupational threat. J Eur Acad Dermatol Venereol. 2016;30:3-4.
33. Trakatelli M, Barkitzi K, Apap C, Majewski S, De Vries E. Skin cancer risk in outdoor workers: a European multicenter case-control study. J Eur Acad Dermatol Venereol. 2016;30(3):5-11.

34. Skotarczak K, Osmola-Mankowska A, Lodyga M, Polanska A, Mazur M, Adamski Z. Photoprotection: facts and controversies. Eur Rev Med Pharmacol. 2015;19(1):98-112.

35. Thompson SC, Jolley D, Marks R. Reduction of solar keratoses by regular sunscreen use. $\mathrm{N}$ England J Med. 1993;329(16):1147-51.

36. Naylor MF, Boyd A, Smith DW, Cameron GS, Hubbard D, Neldner K. High Sun protection factor sunscreens in the suppression of actinic neoplasia. Arch Dermatol. 1995;131(2):170-5.

37. Green A, Williams G, Neale R, et al. Daily sunscreen application and betacarotene supplementation in prevention of basal-cell and squamous-cell carcinomas of the skin: a randomised controlled trial. Lancet. 1999;354(9180):723-9.

38. Darlington S, Williams G, Neale R, Frost C, Green A. A randomized controlled trial to assess sunscreen application and beta carotene supplementation in the prevention of solar keratoses. Arch Dermatol. 2003;139(4):451-5.

39. Ulrich JS, Jurgensen A, et al. Prevention of nonmelanoma skin cancer in organ transplant patients by regular use of a sunscreen: a 24 months, prospective, case-control study. $\mathrm{Br} \mathrm{J}$ Dermatol. 2009;161(3):78-84.

40. Haigis M, Yankner B. The aging stress response. Mol Cell. 2010;40(2):333-44.

41. Radice M, Manfredini S, Ziosi P, et al. Herbal extracts, lichens and biomolecules as natural photo-protection alternatives to synthetic UV filters. A systematic review. Fitoterapia. 2016;114:144-62.

42. Sancar A. Mechanisms of DNA repair by photolyase and excision nuclease (Nobel Lecture). Angew Chem Int Ed Engl. 2016;55(30):8502-27.

43. Sancar A. Structure and function of DNA photolyase and cryptochrome blue-light photoreceptors. Chem Rev. 2003;103:2203-37.

44. Dulbecco R. Reactivation of ultra-violet-inactivated bacteriophage by visible light. Nature. 1949;163(4155):949.

45. Husain I, Carrier WL, Regan JD, Sancar A. Photoreactivation of killing in E. coli $\mathrm{K}-12 \mathrm{phr}-$ cells is not caused by pyrimidine dimer reversal. Photochem Photobiol. 1988;48(2):233-4. 
46. Todo T, Takemori H, Ryo H, et al. A new photoreactivating enzyme that specifically repairs ultraviolet light-induced (6-4)photoproducts. Nature. 1993;361(6410):371-4.

47. Hoeijmakers JH. Genome maintenance mechanisms for preventing cancer. Nature. 2001;411(6835):366-74.

48. Bohr VA, Smith CA, Okumoto DS, Hanawalt PC. DNA repair in an active gene: removal of pyrimidine dimers from the DHFR gene of CHO cells is much more efficient than in the genome overall. Cell. 1985;40:359-69.

49. Mitchell DL. The relative cytotoxicity of (6-4) photoproducts and cyclobutane dimers in mammalian cells. Photochem Photobiol. 1988;48(1):51-7.

50. de Laat WL, Jaspers NGJ, Hoeijmakers JHJ. Molecular mechanism of nucleotide excision repair. Genes Dev. 1999;13(7):768-85.

51. Yarosh D, Alas LG, Yee V, et al. Pyrimidine dimer removal enhanced by DNA repair liposomes reduces the incidence of UV skin cancer in mice. Cancer Res. 1992;52(15):4227-31.

52. Stege H, Roza L, Vink AA, et al. Enzyme plus light therapy to repair DNA damage in ultraviolet-B-irradiated human skin. Proc Natl Acad Sci USA. 2000;97(4):1790-5.

53. Stege H. Effect of xenogenic repair enzymes on photoimmunology and photocarcinogenesis. J Photochem Photobiol B. 2001;65(2-3):105-8.

54. Yarosh D, Klein J, Kibitel J, et al. Enzyme therapy of xeroderma pigmentosum: safety and efficacy testing of T4N5 liposome lotion containing a prokaryotic DNA repair enzyme. Photodermatol Photoimmunol Photomed. 1996;12(3):122-30.

55. Yarosh D, Klein J, O'Connor A, Hawk J, Wolf Rafal E. Effect of topically applied $\mathrm{T} 4$ endonuclease $\mathrm{V}$ in liposomes on skin cancer in xeroderma pigmentosum: a randomised study. Xeroderma Pigmentosum Study Group. Lancet. 2001;357(9260):926-9.

56. Puviani M, Barcella A, Milani M. Efficacy of a photolyase-based device in the treatment of cancerization field in patients with actinic keratosis and nonmelanoma skin cancer. G Ital Dermatol Venereol. 2013;148(6):693-8.

57. Giustini S, Miraglia E, Berardesca E, Milani M, Calvieri S. Preventive long-term effects of a topical film-forming medical device with ultra-high UV protection filters and DNA repair enzyme in xeroderma pigmentosum. Case Rep Dermatol. 2014;6(3):222-6.

58. Rstom SA, Martinez ZAB, Rezze GG, Paschoal FM. Evaluation of the effects of a cream containing liposome encapsulated photolyase and SPF 100 sunscreen on facial actinic keratosis: clinical, dermoscopic, and confocal microscopy based analysis. Surg Cosmet Dermatol. 2014;6(3):22631.

59. Puig S, Puig-Butillé JA, Díaz MA, Trullas C, Malvehy $\mathrm{J}$, et al. Field cancerisation improvement with topical application of a filmforming medical device containing photolyase and UV filters in patients with actinic keratosis, a pilot study. J Clin Exp Dermatol Res. 2014;5:220-7.

60. Laino L, Elia F, Desiderio F, et al. The efficacy of a photolyase-based device on the cancerization field: a clinical and thermographic study. J Exp Clin Cancer Res. 2015;19(34):84.

61. Eibenshutz L, Silipo V, De Simone P, et al. A 9-month, randomized, assessor-blinded, parallelgroup study to evaluate clinical effects of filmforming medical devices containing photolyase and sun filters in the treatment of field cancerization compared with sunscreen in patients after successful photodynamic therapy for actinic keratosis. Br J Dermatol. 2016;175(6):1391-3.

62. Vaño-Galván S, Jiménez N, Grillo E, Ballestar A. An observational study on the effectiveness and safety of the combination of a topical product containing photolyase and cryotherapy in patients with actinic keratoses in clinical practice (article in Spanish). Piel. 2016;31(8):532-6.

63. Navarrete-Dechent C, Molgó M. The use of a sunscreen containing DNA-photolyase in the treatment of patients with field cancerization and multiple actinic keratoses: a case-series. Dermatol Online J. 2017;15:23.

64. Moscarella E, Argenziano G, Longo C, Aladren S. Management of cancerization field with a medical device containing photolyase: a randomized, double-blind, parallel-group pilot study. J Eur Acad Dermatol Venereol. 2017;31(9):e401-3.

65. Krutmann J, Berking C, Berneburg M, Diepgen TL, Dirschka T, Szeimies M. New strategies in the prevention of actinic keratosis: a critical review. Skin Pharmacol Physiol. 2015;28(6):281-9.

66. Wang SQ, Virmani P, Lim HW. Consumer acceptability and compliance: the next frontier in sunscreen innovation. Photodermatol Photoimmunol Photomed. 2016;32(1):55-6. 